\title{
Investigation of the Relationship Between Job Performance, Burnout and Workaholism
}

\author{
Cenk AKSOY \\ Dicle University \\ School of Civil Aviation \\ Diyarbakır, Turkey \\ orcid.org/0000-0003-0763-2847 \\ drcenkaksoy@gmail.com
}

\author{
Ayhan YALÇINSOY \\ Dicle University \\ Institute of Social Science \\ Diyarbakır, Turkey \\ orcid.org/0000-0002-0510-1586 \\ ayhanyalcinsoy@gmail.com
}

\begin{abstract}
The research is carried out for police officers working at the Diyarbakir Police Department in the Southeastern Anatolia region of Turkey. The aim of the research is to determine the relationship between the concepts of job performance, burnout, and workaholism of the police officers. Research data are collected by questionnaires and 189 questionnaires were used for the analysis. The correlation, regression, t-Test and Anova analyzes are applied to the research data in the SPSS program. At the end of the research, a low level negative relation is found between the concepts of job performance, burnout, and workaholism. It is also determined that there were no significant differences between the demographic variables and the research subjects at the significance level of 0,05 .
\end{abstract}

Keywords: Job Performance, Burnout, Workaholism

\section{Introduction}

Business life is changing at the same rate with the outside world, which is changing rapidly. This rate of change inevitably affects employees with a positive or negative way. Managers, who are important actors of the business world, tend to evaluate employees performance according to different parameters depending on the conditions of the day. Employees working with this awareness are in a race with other employees either with the expectation of higher income or to make a difference. Performance races of the employees become inevitable, especially given the fact that job performance of private sector employees is tried to be measured with a concrete set of assessment criteria. In this regard, job performance gains more and more importance for employees in every sense.

Efforts to increase work performance drive employees to different psychological or sociological problems. Burnout or popularly known as burnout syndrome is only one of these problems, which has been frequently investigated in recent years by researchers both abroad and at home. Although the syndrome has aspects directly related to the 
period of experiencing it and the work done by the person, the burnout not only depends on the intense work schedule/pressure, but it can also occur due to different reasons.

Another problem that is caused by intense work schedule or excessive work addiction, such as having too much time at work, is the state of being a workaholic. The word workaholic is derived in the same way as alcoholic, tea-holic, and so on. That is to say, the term workaholic is used for the individuals with high level of work relation inspired by the term alcoholic which is used for the individuals with high alcohol relations. In the framework of the above-mentioned approaches, police officers who have a heavy work pressure by profession were selected as research sample. In this framework, the research is looking for an answer to the question "Is there any relation between job performance, burnout and being a workaholic in police officers?" in light of the information in the related literature. Although each concept has been examined in different ways for the policing profession, no research has been found which deals with the three concepts together.

\section{Theoretical Framework}

\subsection{Job Performance}

The issue of how employees who work in the same business or in similar organizations produce better quality services or products compared to the ones working in other organizations that has similar jobs or produce similar products has attracted interest from researchers and has become a subject of various scientific researches (Arslan, 2016).

In this context, towards the end of the 19th century, F.W.Taylor started the first scientific studies on the concept of performance. Taylor published his research in 1911 in a book under the title of Basic Principles of Scientific Management (Taylor, 2003, Sucu, 2000).

It is stated that Taylor pioneered the American people with the idea of performance increase led by himself. Regarding his success, Drucker stated that in the second world war the American people began to raise people who made first class production in a very short time by applying Taylor's ideas. He also suggested that the US is influenced by this idea in eliminating two powerful world economies such as Germany and Japan. Drucker took this idea one step further and stated that manufacturing giants such as Japan, Korea, Singapore, Taiwan and Hong Kong, which are considered as the five tigers of Asia, have achieved their performance by being inspired by Taylor's philosophy of educating workers (Drucker, 1992: 59; Yüksel and Aykaç, 1994: 87).

Especially after 2000 's, the concept of job performance has become the focus of attention by scientists. Researchers on this subject acknowledge that job performance is multifaceted and multi-dimensional (Borman and Motowidlo, 1997). Today, it is possible to come up with many models about job performance developed by researchers.

Performance is a term related to the technical aspect of the working behavior (Motowidlo et al., 1997) and is defined as the works that must be done by the employees in exchange for salaries and other benefits (Rousseau and Parks, 1993). In short, performance can also be described as the result of an employee's work with an intention to make a task assigned to him or her in a certain period of time (Simsek and Oge, 2011). 
Yumusak (2008) has collected the factors that affect the performance of employees under three main groups as economic, physical and psycho-social factors. He listed the wage increases, premium wages and economic benefits as the economic factors. As the physical factors he stated work safety and health as well as the working environment such as temperature, ventilation, lighting and humidity. As for the psychosocial factors that affect the performance of employees, he counted the communication, orientation, education and motivation factors.

Performance is expressed as the level of work that the employees have done according to some criteria previously determined by the managers and the manner of behaviors that the employees put fort while working. The performance evaluation made on the basis of these criteria is the comparison of the current performance of the employees with the their potential performance in the future. Performance appraisal, which is frequently used as human resources applications in recent periods, has attracted intense interest of researchers in this direction. (Gürbüz and Yüksel, 2008).

In human resources management, performance evaluation, which is a process that is not very popular for employees, is both difficult and complex. In the literature, this situation was frequently addressed by researchers. Some criteria are created by the managers depending on the way of doing business. In light of these criteria, employees are subjected to a measurement process according to certain criteria. The main purpose here is to increase the organizational performance as well as the individual performance of the employees. As high efficiency means competitive power in the sector in which it operates, it is important to increase the performance of the workers and the organization. For individuals, this is important not only in terms of financial gains but also job satisfaction, high level career opportunities and social reputation of the employees (Mohrman et al., 1989; Austin and Villanova, 1992; Sonnentag and Freese, 2002; as cited in Yelboga, 2006).

\subsection{Workaholism}

The concept was first coined by Oates in 1968. According to Oates, workaholism, which expresses an emotion, has been presented as an uncontrollable need, excessiveness and as a result, a situation that distorts health and comfort, which negatively affects the relationships with other people around, depending on continuous and long hours of work (McMillan et al. 2001: 69; Seybold and Salamone, 1994: 6).

According to Spence and Robbins, workaholism is a form of behavior that emerges as being unable to disconnect from the work, over-dependence to work, and the inability to give up the idea of working from the mind, by moving away from other activities outside of work in social life (Spence and Robbins, 1992: 161).

According to another approach, individuals with workaholic characteristics are more willing and dedicated than their counterparts. They also have a problem of confidence about the work compared to other employees and feel the need for praise and approval for the work they do (Burke, 2000: 13).

There are different opinions in the researches about the workaholism whether it is positive or negative. The researchers have not reached a consensus on this issue. Looking at the researches in general, it is seen that the workaholism is regarded as negatively. According to these researchers, workaholism is a situation that harms both the employee and the organization he/she works for. Workaholism, which indicates an addiction such as alcoholism, is a negative situation for the health of the individual. Contrary to this view, researchers who consider workaholism positively argue that the 
workaholism makes the individual devoted to and love his/her work, and therefore he/she will succeed in the work he/she does. (Oates, 1971; Schaef and Fassel, 1988; Killinger, 1991; Bayraktaroglu et al., 2009).

\subsection{Burnout}

The concept was first introduced in 1972 by the American psychoanalyst, Herbert J. Freudenberger. Freudenberger coined the concept into the literature in 1974 by a journal published in the Journal of Social Issues. According to Freudenberger, burnout is the state of depletion of internal resources of employees as a result of failure, exhaustion, loss of energy and power, or unpredictable demands (Freudenberger, 1974).

Since 1974, much research has been done on the subject and many scales have been developed to measure burnout. However, the most accepted definition of burnout today is made by C. Maslach. Maslach describe the burnout as a syndrome that occurs due to feelings of physical exhaustion, prolonged fatigue, hopelessness and helplessness encountered in employees who face intense emotional desires as a professional requirement and always have to work with others, and which cause people to exhibit negative behaviors towards other individuals in their working life and in their private lives (Maslach and Jackson, 1981).

Adding dimensions to the concept, burnout was defined by Maslach and Jackson (1986) as "three-dimensional psychological syndrome" as "emotional exhaustion", "desensitization" and "reduction in individual achievement". The development of these three dimensions of burnout can be summarized as follows.

Burnout, first of all, is caused by the exhaustion of the emotional resources of individuals because of the excess work load and continuation of works, which leads to the formation of "emotional exhaustion". The person at this level sees himself/herself physically and emotionally exhausted and worn out, unable to commit himself/herself to his/her work and unable to act adequately responsible to his/her clients. Those who show exhaustion over time are getting away from other people and developing weaker relations with the people they are with. As a result, a condition described as "desensitization" occurs in such persons. The desensitized individual prefers to become isolated/get lonely by removing others from their lives by thinking that they are interfering too much in their lives. At the last stage, the individual who is aware of the negative changes that are happening in him/her sees himself/herself inadequate in the relations he/she has established with his work and people. Negative self-evaluation of the person is considered to be "a decrease in personal achievement" (Maslach and Zimbardo, 1982; Cordes and Dougherty, 1993; Maslach, et al., 2001; Ardic and Polatci, 2009; Arslantaş et al., 2016: 13).

\subsection{Job Performance, Workaholism, and Burnout Relations}

\subsubsection{Job Performance and Burnout}

Burnout is described by Freuderberger in the related literature as the state of depletion of internal resources of employees in the event of failure, exhaustion, loss of energy and power, failure to meet demands due to excessive workload (Freuderberger, 1974). The effects of the burnout on the performance have been investigated in the studies conducted based on this. Bakker et al. (2004) have shown in their study that burnout affects the job performance. Parker and Kulik (1995) found that high level of burnout have a negative impact on job performance. Wrigth et al. (2004) found that some sub-dimensions of burnout are related to job performance. 


\subsubsection{Job Performance and Workaholism}

It can be said that workaholism will have a positive effect on job performance since it is considered, in one aspect, as over-reliance on work and indulgence in work. However, there are also researchers who consider workaholism in a negative way. According to researchers who see workaholism as a health problem, this can affect job performance negatively (Machlowitz, 1980, Korn et al., 1987, Sprankle and Ebel, 1987, Snir and Harpaz, 2004). In studies where job performance is associated with workaholism, it has been found that workaholism has a positive effect on job performance (Shimazu et al., 2010; Gorgievski et al., 2014). A positive relationship was found between the organizational performance as a performance type and workaholism in the research on the relationship between the two concepts (Arsezen, 2017).

\subsubsection{Workaholism and Burnout}

Workaholism and burnout can, in a similar way, lead to problems in the family and working life of the employees, as well as various health problems such as stress and depression. There are studies that show that individuals with high expectation of success have a high likelihood of having burnout, as well as workaholic individuals develop negative attitudes toward their jobs (Keown, 2008). Sometimes the intense efforts and initiatives of individuals that they show in their jobs may encounter pressure and obstacles by their organizations, resulting in negative consequences physically and mentally for such individuals regarded as workaholics. People can feel themselves unsuccessful, tired, helpless, and low-self-confident because of the situations which led negative/unfavorable consequences. As a result, those who are dedicated to work and feel obliged to work constantly are likely to have burnout. (Moorhead and Griffin, 1992). In the studies in which workaholism and burnout were associated, the relation between the two concepts has been examined but different results have been found. Arslantaş et al. (2016: 11) found that there was a positive relationship between the levels of burnout and workaholism in the research they conducted on lawyers. Naktiyok and Karabey (2005) found that the increase in the level of workaholism of academicians/faculty members increased mental, physical and emotional burnout/exhaustion. According to Mohair and Zincirkıran (2014), no significant relationship between the two concepts was found in their research on cashiers.

There is almost no study in the literature that examines job performance, burnout, and workaholism together at the same time. However, a conclusion can be obtained through examining both bilateral comparison studies and making use of the research findings. Research hypotheses that have been produced in accordance with the literature for the determination of this relationship can be developed as follows:

$\mathrm{H}_{1}$ : There is a negative linear relationship between job performance, burnout and workaholism in the subjects surveyed.

$\mathrm{H}_{2}$ : Burnout and workaholism affect job performance.

$\mathrm{H}_{3}$ : Job performance, burnout and workaholism differ according to some demographic variables.

The following research model can be developed from the hypotheses put forth by benefiting from the relevant field literature presumed to explain the relationship between job performance, burnout and workaholism (Figure 1). 


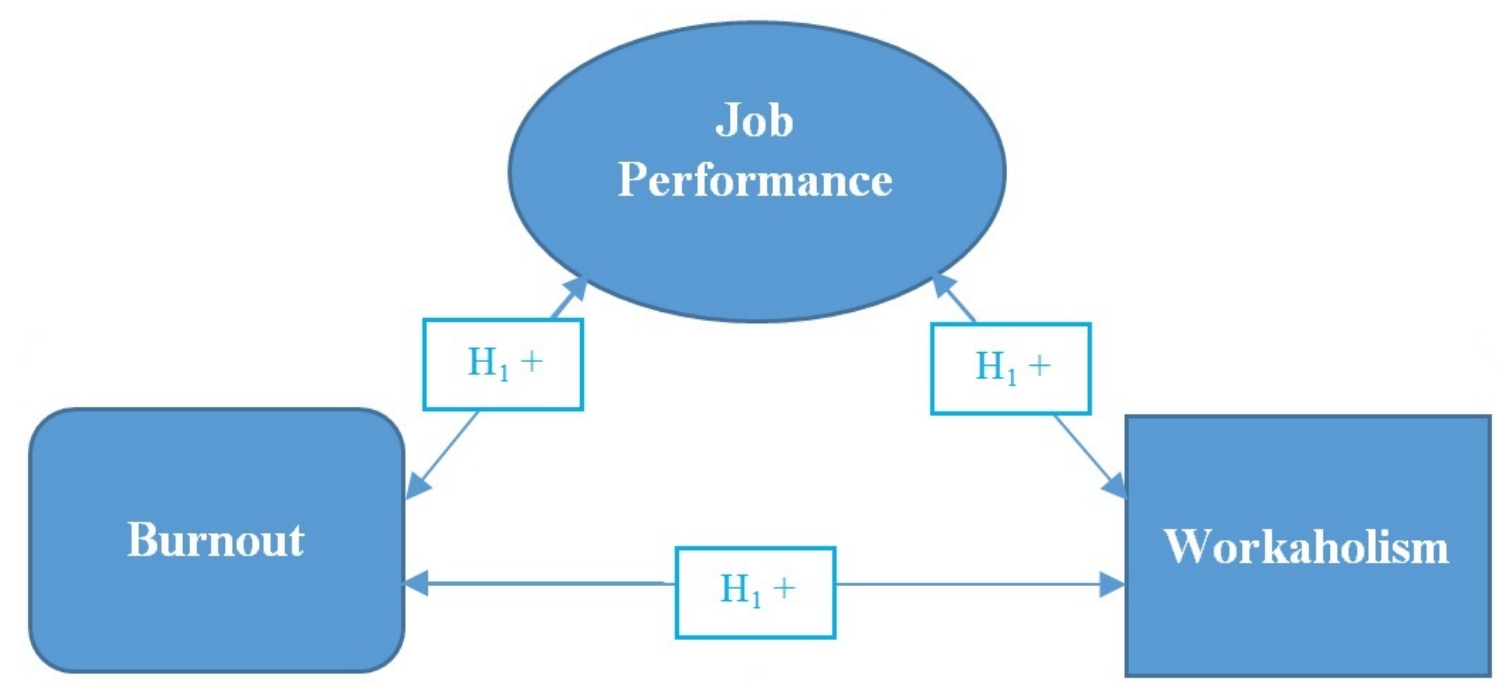

Figure 1: Research Model

\section{Methodology}

\subsection{The Universe and the Sampling of the Research}

This study aims to measure the relationship between the concepts of job performance, burnout and workaholism of the police officers in Diyarbakir city of Turkey. A questionnaire consisting of 43 questions was used except demographic variables to test the hypotheses and the model. These scales were distributed randomly to the police officers of Diyarbakir Police Department in the southeastern city of Turkey. For the purpose of research, the scales were distributed to 300 police officers employed in the Diyarbakir Police Department. 227 of them were returned, but 38 of them were not classified because the questions were not fully answered. A total of 189 scales were used for the analyses.

\subsection{Data Collection Tools}

In collecting the data, 3 separate scales were used to determine the levels of work performance, burnout and workaholism except for the demographic information form.

a) Demographic Variables: The demographic information in the survey includes gender, marital status, age, work experience and income status.

b) The Workaholism Scale: In order to measure the level of workaholism of the employees, the WorkBAT (Working Battery) scale developed by Spence and Robbins (1992) and used in many studies was used in this study. The Cronbach Alpha coefficient of the scale was found to be 0.67 as a result of the reliability analysis. The Turkish Form adapted by Kart (2005) and a two-dimensional scale whose validity and reliability were ensured were utilized in the study. These two sub-dimensions were Work Enjoyment (WE) and Motivation to Work (D). The scale consists of a total of 20 statements (18 positive and 2 negative) in 2 sub-dimensions. There were 10 statements under the Work Enjoyment category and 10 statements under the Motivation to Work category. The skewness and kurtosis values were between -1 and +1 , and the distribution was normal. A 5-point Likert scale was used to determine the extent to which the participants agree with the statements, and the expressions "Strongly Agree, Agree, Undecided, Disagree and Strongly Disagree" were used for each statement on the scales. 
c) The Burnout Scale: The "Maslach Burnout Inventory" developed by Maslach and Jackson (1981) and widely accepted in the field was used to measure the level of burnout. The Maslach Burnout Scale, translated into Turkish by Ergin (1992), consists of 22 statements. The scale was answered with 5-Point Likert method. The Cronbach Alpha coefficient of the scale was found to be 0.89 as a result of the reliability analysis. The skewness and kurtosis values were between -1 and +1 , and the distribution was normal. The expressions "Never, Rarely, Sometimes, Often, Always" were used for each statement on the scales which consist of 5-point Likert-type questions.

d) Job Performance Scale: A scale which consists of 6 questions and adapted by Bakiev (2011) using various scales was used. The Cronbach Alpha coefficient of the scale was found to be 0.73 as a result of the reliability analysis. The skewness and kurtosis values were between -1 and +1 , and the distribution was normal. A 5-point Likert scale was used to determine the extent to which the participants agree with the statements, and the expressions "Strongly Agree, Agree, Undecided, Disagree and Strongly Disagree" were used for each statement on the scales.

\subsection{Data Analysis}

The data were analyzed using the SPSS 18.0 statistical program. The data were evaluated by performing correlation, regression, t-test and ANOVA analyzes. In this study, statistical significance level was accepted as $\mathrm{p}<0.05$.

\section{Findings}

Table 1: Demographic Variables

\begin{tabular}{lcc}
\hline Variables & Percentage & Frequency \\
\hline Number of Participants & $\% 100$ & 189 \\
\hline Gender & $\% 3,2$ & 6 \\
\hline Women & $\% 96,8$ & 183 \\
\hline Men & & \\
\hline Age & $\% 50,8$ & 96 \\
\hline $20-30$ & $\% 49,2$ & 93 \\
\hline $31-40$ & & \\
\hline Marital Status & $\% 90,5$ & 171 \\
\hline Married & $\% 9,5$ & 18 \\
\hline Single & & \\
\hline Income Level & $\% 2,1$ & 4 \\
\hline $3000-4000 T L$ & $\% 91$ & 172 \\
\hline $4001-5000$ TL & $\% 6,9$ & 13 \\
\hline 5001 and over TL & & \\
\hline Work Experience & $\% 83,6$ & 158 \\
\hline $6-10$ years & $\% 14,8$ & 28 \\
\hline $11-15$ years & $\% 1,6$ & 3 \\
\hline $16-20$ years & & \\
\hline
\end{tabular}

The survey was conducted in March and April 2017. From a total of 189 police officers participating in the survey, 6 of them (3.2\%) were women and 183 of them $(96.8 \%)$ were men, as seen in Table $1.96(50.8 \%)$ of the participants were between the 
ages of $20-30$ and $93(49.2 \%)$ of them were between the ages of 31-40. $171(90.5 \%)$ of the participants were married and $18(9.5 \%)$ of them were single. $4(2.1 \%)$ of the participants had an income between 3000-4000 TL, 172 (91\%) of them had an income between 4001-5000 TL, and 13 (6.9\%) of them had an income of more than $5000 \mathrm{TL}$. As for the work experience, it was seen that 158 (83.6\%) of the participants had a work experience between $6-10$ years, $28(14.8 \%)$ of them had $11-15$ years and $3(1.6 \%)$ of them had more than 15 years of work experience.

As shown in Table 2 below, there was a negative linear correlation between job performance, burnout and workaholism. The relationship between them can be ignored because of the fact that the level of this relationship was low. Accordingly, from the research hypothesis, $\mathrm{H}_{1}$ was largely rejected.

Table 2: Correlation between Job Performance, Burnout, and Workaholism

\begin{tabular}{|l|l|ccc|}
\hline \multicolumn{2}{|c}{} & $\mathbf{1}$ & $\mathbf{2}$ & $\mathbf{3}$ \\
\hline 1. Job Performance & \multirow{2}{*}{$\begin{array}{c}\text { Pearson } \\
\text { 2. Burnout }\end{array}$} & 1 & $-0,018$ & $-0,037$ \\
\cline { 1 - 1 } & $\begin{array}{c}\text { Correlation } \\
\text { Coefficient }\end{array}$ & & 1 & $-0,085$ \\
\cline { 1 - 1 } & & & & 1 \\
\hline
\end{tabular}

**Correlation is significant at the 0.05 level (2-tailed).

As shown in Table 3 below (as for job performance), the variables of burnout and workaholism account for $3 \%$ of the total variance. Hence, the $\mathrm{H}_{2}$ hypothesis was rejected.

Table 3: Regression between Job Performance, Burnout and Workaholism

\begin{tabular}{|c|c|l|c|c|c|c|c|}
\hline Dependent Variable & $\mathbf{R}^{2}$ & $\begin{array}{c}\text { Independent } \\
\text { Variable }\end{array}$ & $\mathbf{B}$ & Beta & $\boldsymbol{t}$ & $\mathbf{p}$ & VIF \\
\hline \multirow{2}{*}{ Job Performance } & $\mathbf{0 . 0 2}$ & Burnout & -.011 & -.022 & $-0,29$ & 0.768 & 1.96 \\
\cline { 3 - 8 } & & Workaholism & -.019 & -.039 & $-0,53$ & 0.595 & 1.96 \\
\hline
\end{tabular}

There was no auto correlation in this model as Durbin Watson table shows $1.5<\mathbf{d}$ $=1.96<4$.

In the study, there was no significant difference in the analysis of the differences between the concepts of job performance, burnout and workaholism with the demographic variables such as age $(\mathrm{T}=0,594 ; \mathrm{T}=0,408 ; \mathrm{T}=0,957, \mathrm{p}<0.05)$, gender $(\mathrm{T}=0,742 ; \mathrm{T}=0,316 ; \mathrm{T}=0,208, \mathrm{p}<0.05)$, marital status $(\mathrm{T}=0.183, \mathrm{~T}=0.727, \mathrm{~T}=0.307$, $\mathrm{p}<0.05)$ and work experience $(\mathrm{F}=0,594 ; \mathrm{F}=0,408 ; \mathrm{F}=0,957, \mathrm{p}<0.05)$. Hence, the $\mathrm{H}_{3}$ hypothesis was rejected.

In the study, the mean value of the answers given by the participating police officers about the job performance from the concepts subject to the survey was $\bar{X}: 2.78$. According to this result, it can be said that the level of job performance of the police officers was average, as it fell close to "Undecided" on the scale. The mean value of the police officers' answers to burnout statements was $\bar{X}: 2.35$, which could be interpreted as "Rarely" according to the scale, indicating that the police officers who participated in the survey had a low level of burnout feelings. According to another result of the 
research, the average value of the responses given by the police officers to workaholism statements was $\bar{X}: 3.12$. Since this result corresponds to "Undecided" on the scale, it was conceivable to state that the police officers participating in the survey had a hidden workaholism.

\section{Conclusion and Discussion}

Within the scope of the study on the police officers, the relationship between the concepts of job performance, burnout and workaholism was examined and a low level of negative linear relationship was found between these concepts. Since the relation level was very low, it was neglected and the research hypothesis was rejected. This result was different from the results of the researches previously conducted in different professions about the relationships of the concepts with each other (Nowack et al., 1985, Naktiyok and Karabey, 2005, Ashtari et al., 2009, Swider and Zimmerman, 2010, Tiftik and Zincirkıran, 2014). The result may be due to different reasons. Different results can be obtained if the research can be re-applied to police officers working in different cities and at different positions and in different time intervals. However, the result of this study was consistent with the results of the research conducted by Karatepe and Uludağ (2008) regarding the relationship between job performance and burnout that no relation was found between them.

In the study, no significant difference was determined in the analysis of the differences between the concepts of job performance, burnout and workaholism with the demographic variables such as age, gender, marital status and work experience. From these results, the conclusion regarding the age variation overlaps with the results of Kaya (2010) on burnout in police officers. However, significant differences in burnout, gender and marital status were determined in the same study. In these studies, while the job performance decreases depending on the age, burnout, on the other hand, can increase. Again in these studies, the level of workaholism can vary depending on the level of professional career, age and gender (Kaya, 2010; Zincirkiran and Mete, 2014).

In the study, according to the analysis of the answers given by the participating police officers about the job performance from the concepts subject to the survey, it can be said that the level of job performance of the police officers was average. The analysis results of the police officers' answers to burnout statements can be interpreted that the police officers who participated in the survey had a low level of burnout feelings. This result was consistent with the results of the previous researches (Naktiyok and Karabey, 2005). According to another result of the study, it was conceivable to state that the police officers participating in the survey had a hidden workaholism that might possibly emerge based on the analysis of the responses given by the police officers to workaholism statements.

While a relationship between the concepts was found in the studies previously conducted related to the subject, a meaningful relation between the concepts cannot be determined in this study. This may be due to the research method, research sample and time factor. If the research can be renewed by differentiating these factors, different results might be obtained.

\section{References}


Ardıç, K., Polatçı, S. (2009). Tükenmişlik Sendromu ve Madalyonun Öbür Yüzü: İşle Bütünleşme. Erciyes Üniversitesi İktisadi ve İdari Bilimler Fakültesi Dergisi, 32, 21- 46.

Arsezen, P. (2017). Turizmde İşkoliklik Davranışı, İş Tatmini İle İşletme Performansı Arasındaki İlişkinin Analizi Ve Örgüte Duygusal Bağlılığın Aracı Rolü: Antalya'da Bulunan Beş Yıldızlı Konaklama İşletmelerindeki Yöneticiler Örneği. Kurklareli üniversitesi iktisadi ve idari bilimler fakültesi dergisi, 6(5), 211-227.

Arslan, V. (2016). Yönetici desteğinin iş memnuniyeti, duygu düzenleme becerisi ve örgütsel performans algısı üzerine aracı etkisi: Sağlık sektöründe bir araştırma, DÜ, Sosyal Bilimler Enstitüsü, İşletme Anabilim Dalı, Doktora Tezi.

Arslantaş, M., Soybaş, İ., Yalçınsoy, A. (2016). İşkoliklik ile tükenmişlik arasındaki ilişkinin incelenmesi: avukatlar üzerine bir araştırma, International Journal of Innovative Strategical Social Research, Vol.1, Issue.1, pp.11-18.

Ashtari, Z., Farhady, Y., Khodaee, M. R. (2009). Relationship between job burnout and work performance in a sample of Iranian mental health staff. African journal of psychiatry, 12(1), 71-74.

Austin, J. T., Villanova, P. (1992). The criterion problem:1972-1992. Journal of Applied Psychology, 77(6), 836-874.

Bakiev, E. (2011). Determinants of interpersonal trust, organizational commitment for performance within Kyrgyz National Police, (unpublished dissertation), Orlando: University of Central Florida.

Bakker, A. B., Demerouti, E., Verbeke, W. (2004). Using the job demands resources model to predict burnout and performance. Human Resource Management, 43(1), 83-104.

Bayraktaroğlu, S., Özen Kutanis, R., Dosaliyeva, D. (2009). İşkoliklik ve Örgütsel Bağlılık: Bankacılık Sektöründe Karşılaştırmalı bir Araştırma. 17. Ulusal Yönetim ve Organizasyon Kongresi, 21-23 Mayıs, Eskişehir.

Borman, W. C., Motowidlo, S. J. (1997). 'Task performance and contextual performance: The meaning for personnel selection research', Human Performance, 10: 99-109.

Burke, R. J. (2000). Workaholism in organizations: concepts, results and future directions. International Journal of Management Reviews, Vol. 2, pp. 1-16.

Cordes, C. L., Dougherty, T. W. (1993). A Review and in Integration of Research on Job Burnout, Academy of Management Review, 18 (4), pp. 621-656

Drucker, P. (1992). Yeni Gerçekler (Çev. Birtane Karanakçı) 2.Baskı, Ankara: İş Bankası Kültür Yayınları.

Ergin, C. (1992). Doktor ve hemşirelerde tükenmişlik ve Maslach tükenmişlik ölçeğinin uyarlanması, VII. Ulusal Psikoloji Kongresi Bilimsel Çalışmaları El Kitabı, 143154.

Freuderberger, H. (1974). Staff burn-out, Journal of Social Issues, 30 (1), pp. 159-165.

Gorgievski, J., M., Antonio Moriano, J., B. Bakker, A. (2014). Relating work engagement and workaholism to entrepreneurial performance. Journal of Managerial Psychology, 29(2), 106-121. 
Gürbüz, S., Yüksel, M. (2011). Çalışma ortamında duygusal zekâ: İş performansı, iş tatmini, örgütsel vatandaşlık davranışı ve bazı demografik özelliklerle ilişkisi. Doğuş Üniversitesi Dergisi, 9(2), 174-190.

Karatepe, O. M., Uludağ, O. (2008). Role stress, burnout and their effects on frontline hotel employees' job performance: evidence from Northern Cyprus. International Journal of Tourism Research, 10(2), 111-126.

Kart, M. (2005). Reliability and validity of the workaholism battery (work-bat): Turkish form, Social Behavior \& Personality, 33(6), 609-618.

Kaya, O. Ş. (2010). Ankara ilinde çalışan polislerin tükenmişlik düzeylerinin bazı değişkenler açısından incelenmesi. Yayınlanmamış Yüksek Lisans Tezi.

Killinger, B. (1991). Workaholics: The respectable addicts. New York: Simon \& Schuster.

Korn, Errol. R., Pratt, George. J., Lambrou, P. T. (1987). Hyper-performance: The A.I.M. Strategy For Releasing Your Business Potential. New York: John Wiley \& Sons,

Machlowitz, M. (1980). Workaholics: Living With Them, Working With Them. Reading, MA: Addison-Wesley.

Maslach, C., Zimbardo, P. G. (1982). Burnout-The Cost of Caring, Prentice-Hall, Inc., Englewood Cliffs, New Jersey.

Maslach, C., Shaufeli, W. B. ve Leiter M. P. (2001). Job Burnout, Annual Review Psychology, 52, ss. 397-422.

McMillan, L. H. W., O'Driscoll, M. P., Marsh, N. V., Brady E. C. (2001). Understanding Workaholism: Data Synthesis, Theoretical Critique, and Future Design Strategies, International Journal of Stress Management, 8 (69). https://doi.org/10.1023/A:1009573129142

Mohrman, A.M., Restnick, W.S., Lawler, E. E. (1989). Designing Performance Appraisal Systems, Jossey Bass Publ.

Motowidlo, S. J., Borman, W. C., Schmit, M. J. (1997). A theory of individual differences in task and contextual performance. Human Performance, 10, 71-83.

Naktiyok, A., Karabey, C. N. (2005). İşkoliklik ve tükenmişlik sendromu. Atatürk Universitesi İktisadi ve İdari Bilimler Dergisi, 19(2).

Nowack, K. M., Gibbons, J. M., Hanson, A. L. (1985). Factors affecting burnout and job performance of resident assistants. Journal of College Student Personnel, 26(2), 137-142.

Oates, W. (1971). Confessions of a Workaholic: The Facts about Work Addiction. New York: World Publishing Co.

Parker, P. A., Kulik, J. A. (1995). Burnout, self-and supervisor-rated job performance, and absenteeism among nurses. Journal of Behavioral Medicine, 18(6), 581-599.

Rousseau, D. M., Parks, J. M. (1993). The contracts of individuals and organizations. In L. L. Cummings \& B. M. Staw (Eds.), Research in Organizational Behavior (pp. 1-47). Greenwich, CT: JAI Press.

Schaef, A. W., Fassel, D. (1988). The Addictive Organization. Harper \& Row Publishers. 
Seybold, K. C., Salomone, P. R. (1994). Understanding Workaholism: A Review of Causes and Counselling Approaches. Journal of Counselling \& Development, 73 (1), 4-9. https://doi.org/10.1002/j.1556-6676.1994.tb01702.x

Shimazu, A., Schaufeli, W. B., Taris, T. W. (2010). How does workaholism affect worker health and performance? The mediating role of coping. International journal of behavioral medicine, 17(2), 154-160.

Snir, R., Harpaz, I. (2004). Attitudinal and Demographic Antecedents of Workaholism. Journal of Organizational Change Management, 17, 520-536.

Sonnentag, S., Frese, M. (2002). Performance Concepts and Performance Theory. In S. Sonnentag (Ed.) Psychological Management of Individual Performance (p.4-25). John Wiley \& Sons, Ltd.

Spence, J. T., Robbins, A., S. (1992). Workaholism: Definition, Measurement And Preliminary Results. Journal of Personality Assessment, 58, 160-178.

Sprankle, J. K., Ebel, H. (1987). The Workaholic Syndrome. Walker.

Sucu, Y. (2000). Geçmişten günümüze yönetim düşüncesindeki gelişmeler: bütünleştirici bir durumsallık modeli. Ankara: Elit Yayıncılık.

Swider, B. W., Zimmerman, R. D. (2010). Born to burnout: A meta-analytic path model of personality, job burnout, and work outcomes. Journal of Vocational Behavior, 76(3), 487-506.

Şimşek, M. Ş., Öge, S. (2011). İnsan Kaynakları Yönetimi, Konya: Eğitim Akademi Yayınları.

Taylor, F.W. (2003), Bilimsel Yönetimin İlkeleri, (Çev.: Akın, H.Bahadır), Konya: Çizgi Kitabevi.

Tiftik, H., Zincirkıran, M. (2014). A study on employees in context of organizational commitment, job performance, burnout and workaholism: A research on cashiers. International Journal of Sciences: Basic and Applied Research (IJSBAR), 15(1), 171-184.

Wright, T. A., Hobfoll, S. E. (2004). Commitment, psychological well-being and job performance: An examination of conservation of resources (COR) theory and job burnout. Journal of business and management, 9(4), 389.

Yelboğa, A. (2006). Kişilik Özellikleri ve İş Performansi Arasindaki İlişkinin İncelenmesi.“. İş, Güç” Endüstri İlişkileri ve İnsan Kaynaklari Dergisi, 8(2), 196-211.

Yumuşak, S. (2008). İşgören Verimliliğini Etkileyen Faktörlerin İncelenmesine Yönelik Bir Alan Araştırması. Süleyman Demirel Üniversitesi Iktisadi ve İdari Bilimler Fakültesi Dergisi, C.13, S.3 s.241-251.

Yüksel, Ö., Aykaç, B. (1994). Frederick Taylor'un Görüşlerinin Değerlendirilmesinde Yeni Bir Yaklaşım, Amme İdaresi Dergisi, C: 27, S: 4 (Aralık).

Zincirkıran, M., Mete, M. (2014). İşkoliklik İş-Aile Çatışması İlişkisinin Yapısal Eşitlik Modeli ile İncelenmesi: Sağlık İşletmelerinde Bir Uygulama. Finans Politik \& Ekonomik Yorumlar Dergisi, 51 (590), ss: 103, 114. 